\title{
Chromosome numbers in Begonia. $3^{*}$
}

\author{
R. A. H. Legro ${ }^{1}$ and J. Doorenbos ${ }^{2}$ \\ 1 Laboratory of Plant Taxonomy and Plant Geography and \\ 2 Laboratory of Horticulture, Agricultural University, Wageningen, the Netherlands
}

Received: 30 March 1973

\section{Summary}

The somatic chromosome numbers of 34 species of Begonia were counted. The following numbers were found: 26, 38, 52 (African species), 22, 30, 44 (Asiatic species), 26,28, 52, 56, 68 and possibly 104 (American species). All numbers could be fitted into previously established polyploid series. In the discussion it is emphasized that triploidy must have played an important role in the evolution of Begonia species.

\section{Introduction}

In previous publications (Legro \& Doorenbos, 1969, 1971) the somatic chromosome numbers of 190 species of Begonia were given. The variation was found to be considerable. Twenty-two different numbers were counted, ranging from 16 to 156 . This complicated situation is considerably clarified if the species are arranged into sections. Most sections were found to be characterized by one basic chromosome number, from which the other numbers within the section (if any) have been derived by polyploidy.

Since our second paper a number of species have become available for study which had never been examined cytologically. Among these are species belonging to four sections not represented in previous work.

\section{Material and methods}

Much of the material for the present study was generously supplied by the directors of the botanic gardens at Edinburgh, Glasgow, Kew, München and Frankfurt. The McKelly Seed Fund of the American Begonia Society, Mr R. Ziesenhenne and Mrs Thelma O'Reilly kindly sent to us material from private American collections. The following species were grown from plants or seed collected in nature: an unidentified species collected by $\mathrm{Dr}$ W. J. J. O. de Wilde in Cameroun; B. squamulosa Hook.f. collected near Ebolowa, Cameroun, also by Dr de Wilde; $B$. rostrata Welw., collected at Misa Höhe, Togo, by Mr F. J. Breteler; B. laciniata Roxb. collected in N. Thailand, about $150 \mathrm{~km}$ SE of Vientiane and sent by Mrs T. van den Eelaart-de Sitter; B. naumoniensis Irmsch., collected in New Guinea by Mr J. F. U. Zieck; and B. rosaeflora Hook.f., collected by Dr Barbara Pickersgill in Ayacucho, Peru.

* Publication 389, Laboratorium voor Tuinbouwplantenteelt, Landbouwhogeschool, Wageningen, the Netherlands. 
The species were identified with the help of the available descriptions, not by comparison with type material. Voucher specimens have been deposited in WAG, the herbarium of the Department of Plant Taxonomy and Plant Geography at Wageningen. Colour transparencies and photographs are available at the Department of Horticulture.

The cytological methods applied were similar to those described in the first paper of this series.

\section{Results}

The results are summarized in Table 1 . As in the two previous papers, the sections have been grouped in the order given in Irmscher's review (1925). Within each section, the order of the species is alphabetical. The somatic chomosome number of each species is given. Brackets around a number indicate that only a small number of clear metaphase plates could be found, which was considered to be insufficient for definitive conclusions. All species listed have been studied cytologically for the first time, except B. sulcata Scheidw., already counted by Legro \& Doorenbos (1969), but with an erroneous result which now can be corrected.

Table 1. Somatic chromosome numbers in Begonia.

\begin{tabular}{|c|c|c|c|}
\hline African species & & B. confertiflora Gardner & (56) \\
\hline Mezierea & & Doratometra & \\
\hline B. seychellensis Hemsl. & 26 & B. wallichiana Steud. & 26 \\
\hline Squamibegonia & & Scheidweileria & \\
\hline B. poculifera Hook.f. & 38 & B. inciso-serrata A.DC. & 56 \\
\hline Scutobegonia & & Pritzelia & \\
\hline B. sp. from Cameroun & 26 & B. capanemae Brade & (56) \\
\hline B. sp . from Liberia & 52 & B. dietrichiana Irmsch. & (56) \\
\hline Tetraphila & & B. odeteiantha Handro & (56) \\
\hline B. mauricei Ziesenhenne & 38 & Bradea & \\
\hline B. molleri (C.DC.) Warb. & 38 & B. rufosericea Toledo & (56) \\
\hline B. squamulosa Hook.f. & 38 & Huszia & \\
\hline Rostrobegonia & & B. rosaeflora Hook.f. & 28 \\
\hline B. rostrata Welw. & 38 & Hydristyles & \\
\hline Quadrilobaria & & B. sp. & 52 \\
\hline B. sp. from Madagascar & (38) & $\begin{array}{l}\text { Ruizopavonia } \\
\text { B. roezlii Regel }\end{array}$ & \\
\hline Asiatic species & & Gireoudia & \\
\hline Reichenheimia & & B. bettinae Ziesenhenne & 28 \\
\hline B. moreliï Irmsch. & 30 & B. hispida-villosa Ziesenhenne & 28 \\
\hline B. nuri Irmsch. & 44 & B. pinetorum A.DC. & 28 \\
\hline Platycentrum & & B. pruinata A.DC. & 28 \\
\hline B. laciniata Roxb. from N. Thailand & 22 & Saueria & \\
\hline B. sikkimensis A.DC. & 22 & B. sulcata Scheidw. & 68 \\
\hline Petermannia & & Begoniastrum & \\
\hline B. naumoniensis Irmsch. & 30 & $\begin{array}{l}\text { B. guaduensis HBK } \\
\text { B. paulensis A.DC. }\end{array}$ & $\begin{array}{r}(104) \\
(52)\end{array}$ \\
\hline American species & & B. serratifolia C.DC. & (104) \\
\hline $\begin{array}{l}\text { Steineria } \\
\text { B. caraguatatubensis Brade }\end{array}$ & $(56)$ & B. venosa Skan & $(52)$ \\
\hline
\end{tabular}




\section{Discussion}

Among the African species, two belong to sections not previously studied: Mezierea (B. seychellensis, $2 \mathrm{n}=26$ ), and Quadrilobaria (B. sp. from Madagascar, $2 \mathrm{n}=38$ ). The latter, received from the Botanic Garden at Münich as 'species from Bekulosa'. could not be matched with any of the species of Quadrilobaria described so far. It appears to be related to $B$. francoisii Gagnep., but the leaves are not quite so large and are completely smooth. The prevalent chromosome numbers among the African Begonias appear to be 26 and 38. It is tempting to regard 38 as having evolved from 26 as a triploid number (39, with subsequent loss of the odd chromosome). This possibility was underlined by the discovery that an unidentified species of the section Scutobegonia, collected by Dr W. J. J. O. de Wilde in Cameroun, has 26 chromosomes, while another species of this section (received without name or habitat from the late Dr. E. Irmscher's collection of living plants, but present among herbarium material in WAG collected by Mr F. J. Breteler in Liberia) has 52 chromosomes. We venture the hypothesis that the basic number of Scutobegonia is $2 n=26$, and that the previously determined numbers of $2 n=34-38$ have been derived from the triploid level.

In the large section Tetraphila only $2 \mathrm{n}=38$ has been found so far. It should be noted that a few times $2 \mathrm{n}=36$ has been counted, usually in plants that also had cells with $2 \mathrm{n}=38$. A possible explanation is that contraction is retarded in one pair of chromosomes, but this hypothesis could not be tested.

$B$. maurice $i$ has been included among the African species although it is stated that it was collected on Trinidad. Ziesenhenne formed a new section Irmschera for it. To us, however, it seems to be a representative of Tetraphila, and as we find it hard to believe that it would hitherto have been overlooked on Trinidad, we doubt the American origin until this is confirmed by further evidence.

Among the Asiatic species studied, B. nuri Irmsch. should be noted as the first species of Reichenheimia with $2 n=44$ chromosomes. This again is a case in which triploidy must have played a role, unless the ancestor of $B$. nuri had 22 chromosomes, in which case the species of Reichenheimia with 30-34 chromosomes represent the triploid level. However, so far no species of Reichenheimia with $2 \mathrm{n}=22$ has been found.

$B$. laciniata Roxb. from N. Thailand has been included because the forms commonly cultivated come from further south. The present form is an upright plant, 50 to $70 \mathrm{~cm}$ high, which could not be matched with any of the varieties distinguished by Irmscher (1939).

A plant from seed sent by Mr Zieck from New Guinea tallies in every respect with the description of $B$. naumoniensis Irmsch., except that the picture accompanying the description shows a female flower with 5 tepals, whereas the present plant has only 3 . Species of Petermannia with 3 female tepals are not numerous. The present plant, if not $B$. naumoniensis, could possibly be $B$. eliasii Warb. but the description of the latter is too short to permit identification.

The following American species merit further comment. B. wallichiana Steud. was believed by its author to come from India, but in confirmity with most authorities we assume here that it is of American origin. The species of the section Doratometra, to which $B$. wallichiana belongs, are closely related to those of Begoniastrum. This is confirmed by the chromosome number of $2 n=26$, which is probably the basic number of both sections, although it has not yet been found in Begoniastrum. After many fruitless efforts, a few clear metaphase plates could be found in four Begoniastrum 
species the chromosomes of which had so far been elusive. For these species 52 and 104 chromosomes were counted, although still better material is required before this can be regarded as absolutely proven. Within Begoniastrum, we now have a polyploid series of 52, 78, 104 and 156. In addition, there are several species, especially from Brazil, which have $2 n=32$ and $2 n=34$. The latter number we now regard as derived from the triploid number (39), analogous to the situation in other sections, e.g. Scutobegonia. In their turn, these triploid numbers have been doubled and yielded plants like $B$. cucullata Willd. with $2 \mathrm{n}=64$ and the cultivars of $B$. semperflorens $\mathrm{Lk} \&$ Otto with $2 \mathrm{n}=68$ (Zeilinga, 1962). Perhaps $B$. sulcata Scheidw. for which we previously published $2 n=72$ but which was now shown to have $2 n=68$ has a similar origin, as it seems to be related to Begoniastrum.

From Kew we received a plant under an erroneous name which undoubtedly belongs to the section Hydristyles, although it could not be matched with any of the six species described within this section. It has 52 chromosomes. The same number was found for the first representative of Ruizopavonia to be counted, $B$. roezlii Regel (B. lyncheana Hook.f.). Unfortunately, species like $B$. convallariodora C.DC. and $B$. cooperi C.DC., grown in our collection and more typical of Ruizopavonia than $B$. roezlii, could not be counted yet.

\section{Corrections}

Since our previous publications we have had second thoughts about the identity of a few species. $B$. inflata Graham and $B$. popenoei Standley should be deleted from the first paper of this series. The first was probably a hybrid of $B$. inflata and $B$, roxburghii A.DC., the second is a true species (it is reproduced by seed) but remains unidentified for the moment. The publication by Ziesenhenne (1972) of the type specimen of $B$. lindleyana Walp. has shown that this is the plant which we have called B. sparsipila Baker in our second paper. This leaves us without a name for the plant received from the Irmscher collection as $B$. lindleyana Walp. The species from Brazil identified as $B$. crinita Oliv. we would now prefer to call $B$. setulosa Klotzsch. Finally, a slip of the pen: $B$. parviflora Schott should be $B$. parviflora Klotzsch.

\section{Acknowledgments}

The authors are indebted to Mr J. J. Karper who managed to keep even the most difficult species in perfect condition, and to Mrs A. Blacquière-Mulder, Miss R. van Oostveen and Miss O. A. van Oosten for their work at the microscope.

\section{References}

Irmscher, E., 1925. Begoniaceae, in A. Engler \& K. Prantl., Die natürlichen Pflanzenfamilien, 2nd ed., Vol. 21: $548-588$.

Irmscher, E., 1939. Die Begonien Chinas. Mitt. Inst. allg. Bot. Hamburg 10: 427-557.

Legro, R. A. H. \& J Doorenbos, 1969. Chromosome numbers in Begonia. Neth. J. agric. Sci. 17: $189-202$.

Legro, R. A. H. \& J. Doorenbos, 1971. Chromosome numbers in Begonia. 2. Neth. J. agric. Sci. 19: $176-183$.

Zeilinga, A. E., 1962. Cytological investigations of hybrid varieties of Begonia semperflorens. Euphytica 11: $126-136$

Ziesenhenne, R., 1972. Begonia lindleyana clarified. Begonian 39 (2) 28-30, 36. 